\title{
Editorial: Hail and Farewell
}

\author{
Seth S. Leopold MD
}

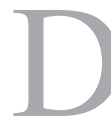

uring my brief span as an active-duty soldier in the Army, I remember finding one military ceremony, the "Hail and Farewell," especially moving. The Hail and Farewell is an opportunity to welcome newcomers to the team, and recognize those retiring or otherwise departing. That a single event allows the enterprise to honor every contributor, even as it demonstrates continuity and conveys that the whole is greater than any of its parts.

But the relationship between the ceremony's name to the event itself has always troubled me. "Hail and

The author certifies that neither he, nor any members of his immediate family, have any commercial associations (such as consultancies, stock ownership, equity interest, patent/ licensing arrangements, etc.) that might pose a conflict of interest in connection with the submitted article.

The opinions expressed are those of the writers, and do not reflect the opinion or policy of $\operatorname{CORR}^{\circledR}$ or The Association of Bone and Joint Surgeons ${ }^{\circledR}$.

S. S. Leopold Editor-In-Chief, Clinical Orthopaedics and Related Research ${ }^{\circledR}$, Philadelphia, PA, USA

S.S. Leopold MD (凶) Clinical Orthopaedics and Related Research ${ }^{\circledR} 1600$ Spruce Street Philadelphia, PA, 19013 USA Email: sleopold@clinorthop.org

All ICMJE Conflict of Interest Forms for authors and Clinical Orthopaedics and Related Research ${ }^{\circledR}$ editors and board members are on file with the publication and can be viewed on request.
Farewell" is named for the last line in Catullus 101 [2], in which the despairing poet Gaius Valerius Catullus laments the death of his brother. Those doleful words always seemed a poor match for the eponymously named event. While Hail and Farewell in the Army always involved goodbyes, unlike the poem, it never seemed sad to me. Rather, the ceremony reflected the energy of those coming in, and celebrated a turning of the page for those moving on.

In that spirit, I offer an Army-style (and not a Catulline) Hail and Farewell to two publishers, both of which have long relationships with Clinical Orthopaedics and Related Research ${ }^{\circledR}$.

First, with this issue of $C O R R^{\circledR}$ we celebrate our first issue with Wolters Kluwer's Lippincott publishing portfolio. Although this is the beginning of a new relationship, I note that the first half-century or so of CORR's history included a long partnership with Lippincott, which since has become part of Wolters Kluwer's Health business. In a sense, the new partnership with Wolters Kluwer is a coming home of sorts for our Journal. The Senior Editors, the leadership of The Association of Bone and Joint Surgeons ${ }^{\circledR}$, and I are delighted to resume this partnership, as Wolters Kluwer is the only major publisher that specializes in the medical, nursing, and allied-health market. We are proud to be published by a company that also is listed among the 100 "Most Sustainable Corporations in the World" [1]. More immediately, Wolters Kluwer understands the needs of our readers, and is well positioned to help us meet them. Wolters Kluwer's content platform, Ovid, is the world's leading tool of its kind, reaching over 13 million users and 12,500 institutions around the world. In concert with Anna Troise, Vice President, Medical and Open Access Publishing, and John Ewers, Senior Publisher at Wolters Kluwer Health, we at CORR look forward to new opportunities to engage with readers and online users, whether they are trainees, private practitioners, academic orthopaedic surgeons, or scientists.

On the farewell side, as 2017 came to a close, so did a 10-year publishing relationship with the global publishing giant, Springer. CORR enjoyed a decade of extraordinary growth in partnership with Springer, including:

- A nearly tenfold increase in fulltext downloads (usage); readers downloaded CORR articles about 3 million times in 2017.

- A $700 \%$ increase in individuals who see CORR's monthly electronic table of contents; this number now approaches 55,000.

- A near-doubling of institutions around the world with full-text access to CORR; more than 11,000 medical libraries, healthcare systems, and consortia are on this list.

- A more-than-twofold increase in Impact Factor, to 3.897 (placing CORR second among some two dozen general-interest orthopaedic journals). 
EDITORIAL

- A $65 \%$ reduction in throughput time from submission to transmittal of a manuscript for publication since 2008 .

I am grateful to Mr. William Curtis (Executive Vice President for Publishing) for bringing us in to Springer publications. We also thank Ms. Antoinette Cimino (Editorial Director) from Springer, whose support made much of CORR's progress possible. Ms. Cimino helped introduce a thennew editor to important sides of the business that most orthopaedic surgeons (and many medical editors) never see. We are also indebted to the production staff at Springer who worked with the CORR team on a daily basis over the years to ensure the quality of our Journal, in particular our production manager, Joe Cerami. Finally, I extend my personal thanks to the senior editors at Springer with whom I have worked: Sadie Forrester, who introduced me to this job and the ways that journals and publishers can work together to good effect; Ross Hildrew, who since has moved on, but whose insights made the Journalpublisher partnership work so well (and who was always a gentleman and a pleasure to work with); and Sean Beppler, whose considerable expertise with analytics has measurably improved our Journal.

Hail and farewell. The page turns.

\section{References}

1. Kauflin J. The world's most sustainable companies 2017. Available at: https:// www.forbes.com/sites/jeffkauflin/2017/01/ 17/the-worlds-most-sustainable-companies2017/\#2e50f3e04e9d. Accessed: October $11,2017$.

2. Translation Wikisource.: Catullus 101. Available at: https://en.wikisource.org/ wiki/Translation:Catullus_101. Accessed on October 11, 2017. 